\title{
PENGARUH PENGAWASAN INTERNAL DAN KEPEMIMPINAN TERHADAP KINERJA KARYAWAN (STUDI KASUS DI POLITEKNIK LP3I JAKARTA)
}

\author{
Rita Wahyuni \\ Institut Ilmu Sosial dan Manajemen STIAMI \\ Email: rawahyuni@gmail.com
}

\begin{abstract}
ARTIICLE INFO
ABSTRACT

Keywords:

Internal Supervision, Leadership, Employee Performance

This study aims to analyze how much influence internal control, leadership to employee performance level. Sampling method used is Proportionate Random Sampling. The sample in this study followed the formula Slovin, or as many as 70 employees Polytechnic LP3I Jakarta. The data that have fulfilled the validity and reliability test are then processed to produce the regression equation $Y=-12.882+0.852 X 1+0.352$ $X 2$, where $Y$ is the employee performance variable, $X 1$ is the internal control variable and $X 2$ is the leadership variable.

The result of the research also shows that internal control influence to employee performance, leadership influence to employee performance, internal control and leadership have influence to employee performance. The relationship of internal supervision and leadership to employee performance is very strong and internal captive variables and leadership can explain employee's performance of $72.9 \%$, while the rest of $27,1 \%$ is explained by other variables.
\end{abstract}

\section{PENDAHULUAN}

Beban persaingan perusahaan dewasa ini semakin ketat, dan hanya perusahaan yang memiliki keunggulan komparatif dan kompetitiflah yang akan keluar sebagai pemenang dalam era persaingan global. Keunggulan komparatif hanya dapat dilakukan jika kinerja perusahaan berjalan baik, sedangkan keunggulan kompetetitif hanya dapat terjadi jika memiliki keunggulan dari sisi kualitas SDM.

Untuk menciptakan sumber daya manusia yang handal membutuhkan pengelolaan yang baik agar Kinerja Karyawan lebih optimal. Pencapaian tujuan perusahaan dipengaruhi oleh Kinerja Karyawan perusahaan itu sendiri. Maka dari itu perusahaan membutuhkan sumber daya manusia yang berpotensial dan berkualitas, baik dari segi pemimpin maupun karyawan pada pola tugas, tanggung jawab, berdaya guna sesuai dengan peraturan dan pengawasan yang merupakan penentu tercapainya tujuan perusahaan.

Suatu perusahan yang telah berjalan sebaiknya memantau seluruh kegiatan operasionalnya. Sebuah pengawasan digunakan untuk membantu memantau kegiatan-kegiatan perusahaan. Pengawasan internal sangat penting, antara lain untuk memberikan perlindungan bagi entitas terhadap kelemahan manusia serta untuk mengurangi kemungkinan kesalahan dan tindakan yang tidak sesuai dengan aturan. Pengelolaan dan penerapan pengawasan internal yang baik maka suatu perusahaan akan lebih mudah dalam pencapaian tujuannya.

Untuk menjaga agar motivasi kerja tidak menurun, perlu ada pengawasan internal. Pengimplementasian pengangasan/ pengawasan internal yang baik pada semua struktur organisasi dalam perusahaan, dapat disediakan menjamini prestasi dari sasaran kinerja yang efektif dan efisien dalam perusahaan. Jika pengawasan internal lemah maka akan mengakibatkan motivasi kerja menurun, kekayaan perusahaan tidak terjamin keamanannya, informasi akuntansi yang ada tidak teliti dan tidak dapat dipercaya kebenarannya, tidak efisien dan efektifnya kegiatan-kegiatan operasional perusahaan serta tidak dapat dipatuhinya kebijakan yang telah ditetapkan.

Upaya-upaya dalam meningkatkan Kinerja Karyawan selain pengawasan internal juga dapat dilakukan dengan Gaya Kepemimpinan. Seorang pemimpin yang ideal harus memiliki Gaya Kepemimpinan yang baik sehingga dapat meningkatkan kinerja karyawannya. Gaya Kepemimpinan seorang pemimpin sangat diperlukan dalam suatu organisasi karena maju mundurnya suatu organisasi tergantung seberapa baik pemimpin dapat memainkan perannya agar organisasi tersebut terus hidup dan berkembang. Gaya 
kepemimpinan yang baik adalah gaya kepemimpinan yang dapat memberikan motivasi kerja pada bawahannya.

Begitu pula halnya dengan Politeknik LP3I Jakarta, Jakarta, kinerja karyawan di Politeknik LP3I Jakarta belum berjalan maksimal karena masih terdapat bebrapa karyawan yang kurang disiplin dalam bekerja misalnya terlambat masuk kerja. Pada perusahaan Politeknik LP3I Jakarta Jakarta juga belum menerpakan pengelolaan pengawasan internal dengan baik, misalnya masih kurangnya pengawasan dari pimpinan Politeknik LP3I Jakarta secara langsung karena pemimpin tidak selalu berada diperusahaan sehingga masih banyak ruang bagi karyawan untuk melakukan kecurangan dan pertukaran informasi yang berkaitan dengan kegiatan operasional perusahaan juga menjadi sedikit terhambat.

Berdasarkan uraian di atas, penulis tertarik untuk mengetahui (1) Seberapa besar pengaruh pengawasan internal terhadap kinerja karyawan ? ; (2) Seberapa besar pengaruh kepempimpinan terhadap kinerja karyawan ?; (3) Seberapa besar pengaruh pengawasan internal dan kepemimpinan secara simultan terhadap kinerja karyawan?

\section{KAJIAN LITERATUR}

1. Pengawasan internal

a. Pengertian Pengawasan Internal

Pengawasan internal menurut Committee of Sponsoring Organization of the Tread way Commission (Sawyer, 2005: 144) adalah :

"Proses, dipengaruhi oleh dewan entitas direksi, manajemen dan personel lain, yang dirancang untuk memberikan keyakinan memadai tentang pencapaian sasaran dalam kategori berikut:

1) Efektivitas dan efisiensi operasi.

2) Tingkat keandalan pelaporan keuangan.

3) Kepatuhan terhadap hukum dan peraturan yang berlaku. pengawasan intern adalah proses yang dirancang untuk memberikan kepastian yang layak mengenai pencapaian tujuan manajemen tentang reliabilitas pelaporan keuangan, efektivitas dan efisiensi operasi, dan kepatuhan terhadap hukum dan peraturan yang berlaku (Arens, 2006:412)"

\section{b. Tujuan pengawasan internal}

Menurut Tunggal dalam bukunya Struktur pengawasan Intern (1995:2) terdapat 4 tujuan pengawasan internal, yaitu: (1) Untuk menjamin kebenaran data akuntansi; (2) Untuk mengamankan harta kekayaan dan catatan pembukuannya; (3) Untuk menggalakkan efisiensi usaha dan (4) Untuk mendorong ditaatinya kebijakan pimpinan yang telah digariskan.

\section{c. Dimensi dan Indikator Pengawasan Internal}

Menurut Mangkunegara (2009: 14), dimensi dan indikator pengawasan internal adalah sebagai berikut :

1) Dimensi atribut individu, yang terdiri dari indikator : kemampuan, keahlian, latar belakang.

2) Dimensi upaya kerja, yang terdiri dari indikator : persepsi, attitude, personality, pembelajaran dan motivasi.

3) Dimensi dukungan organisasi yang terdiri dari indikator : sumberdaya, kepemimpinan, penghargaan dan struktur organisasi

\section{Kepemimpinan}

\section{a. Definisi Kepemimpinan}

Kepemimpinan dapat diartikan sebagai proses mempengaruhi dan mengarahkan para pegawai dalam melakukan pekerjaan yang telah ditugaskan kepada mereka.

Sebagaimana didefinisikan oleh Stoner, Freeman, dan Gilbert (1995), kepemimpinan adalah the process of directing and influencing the task related activities of group members. Kepemimpinan adalah proses dalam mengarahkan dan mempengaruhi para anggota dalam hal 
berbagai aktivitas yang harus dilakukan. Lebih jauh lagi, Griffin (2000) membagi pengertian kepemimpinan menjadi dua konsep, yaitu sebagai proses, dan sebagai atribut.

\section{b. Fungsi Kepemimpinan}

Funsi Kepemimpinan adalah (1) Pemimpin sebagai eksekutif ( executive Leader); (2) Pemimpin sebagai penengah; (3) Pemimpin sebagai penganjur; (4) Pemimpin sebagai ahli dan (5) Pemimpin diskusi

Tipe pemimpin yang seperti ini dapat dijumpai dalam lingkungan kepemimpinan yang demokratis dimana komunikasi memegang peranan yang sangat penting. Seseorang yang secara lengkap memenuhi kriteria kepemimpinan demokratis ialah orang yang menerima peranannya sebagai pemimpin diskusi.

\section{c. Tipe - tipe kepemimpinan}

Tipe-tipe kepemimpinan dibagi menjadi (1) Tipe Otokratik yaitu seorang pemimpin yang otoriter akan menunjukkan sikap yang menonjol "keakuannya; (2) Tipe Paternalistik, yaitu tipe pemimpin paternalistik hanya terdapat di lingkungan masyarakat yang bersifat tradisional.; (3) Tipe Kharismatik, yaitu tipe karakteristiknya yang khas dan sangat memikat.; (4) Tipe Laissez Faire, yaitu pemimpin yang berpandangan bahwa umumnya organisasi akan berjalan lancar dengan sendirinya karena para anggota organisasi terdiri ari orang-orang yang sudah dewasa; (5) Tipe Demokratis

\section{d. Dimensi dan Indikator Kepemimpinan}

Menurut Amirullah dan Budiyono (2004: 244-262), Dimensi dan indikator Kepemimpinan adalah :

Dimensi :

1) Efektifitas Kepemimpinan, dengan indikator : pengambilan keputusan, fungsi kepemimpinan, bersikaf ramah dan mudah ditemui.

2) Perilaku Kepemimpinan, dengan indikator : suppportif, direktif, partisipatif dan orientasi prestasi.

3) Motivasi Kepemimpinan dengan dimensi, dengan indikator : kemampuan memotivasi bawahan, reward and punishment

\section{Kinerja Karyawan}

\section{a. Pengertian Kinerja}

Kinerja merupakan hasil kerja karyawan dalam bekerja untuk periode waktu tertentu dan penekanannya pada hasil kerja yang diselesaikan karyawan dalam periode waktu tertentu. (Timpe, 1993, p. 3). Kinerja yang tinggi dapat tercapai oleh karena kepercayaan (trust) timbal balik yang tinggi di antara anggota - anggotanya artinya para anggota mempercayai integritas, karakteristik, dan kemampuan setiap anggota lain.

\section{b. Cara - Cara untuk Meningkatkan Kinerja}

Berdasarkan pernyataan menurut Timpe (1993) cara - cara untuk meningkatkan kinerja, antara lain (p. 37) (1) Diagnosis ; (2) dan (3) Tindakan.

\section{c. Dimensi dan Indikator Kinerja Karyawan}

Menurut Stephen P. Robins (1994 : 56); Gery Dessler (1995 ; 57) dalam Pabundu (2004: 121128), dimensi dan indikator kinerja adalah sebagai berikut :

1) Dimensi Kualitas kerja, yang terdiri dari indikator : Menyelesaikan pekerjaan sesuai mekanisme, Bekerja keras

2) Dimensi Kuantitas kerja, yang terdiri dari indikator : Bekerja secara tim, saling mengisi dan mendukung

3) Dimensi Lama jama kerja, yang terdiri dari indikator : Masuk dan pulang sesuai waktu, absensi selalu baik 
4) Dimensi Kerjasama, yang terdiri dari indikator : Memberikan tanggungjawab penuh, Memberi penjelasan dengan baik

5) Dimensi supervisi, yang terdiri dari indikator : Tugas sesuai kemampuan, Sesuai dengan waktu dan jumlah pekerjaan

\section{KERANGKA PEMIKIRAN}

Berdasarkan uraian-uraian penjelasan sebelumnya, maka dapat dirumuskan kerangka pemikiran teoritis (paradigma) antara Motivasi Kerja, Budaya Organisasi dan Produktifitas Kerja adalah sebagaimana gambar berikut :

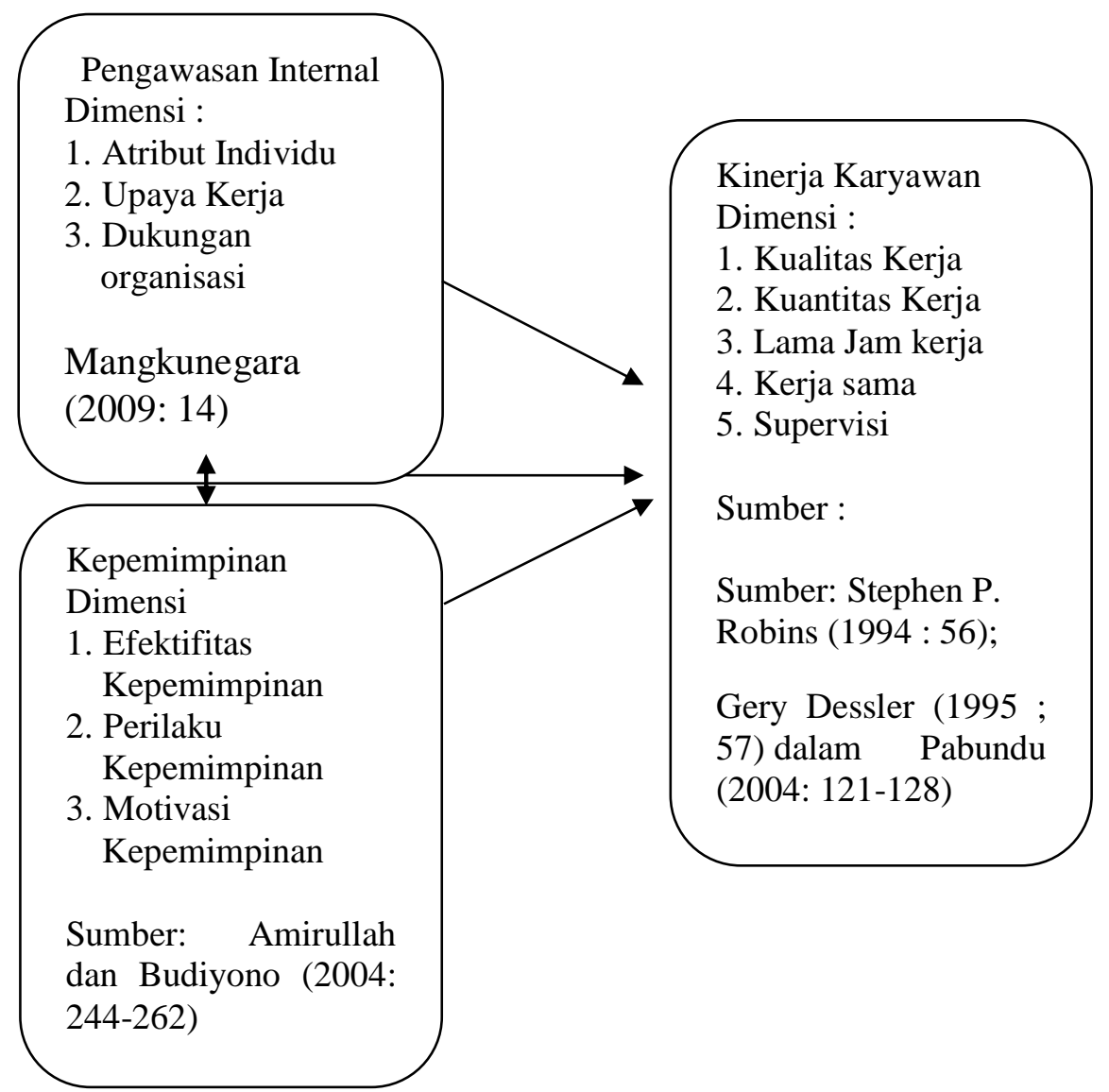

\section{Hipotesis Penelitian}

Hipotesis adalah dugaan sementara yang kebenarannya masih harus dilakukan pengujian (Sugiyono, 2009). Hipotesis ini dimaksudkan untuk memberi arah bagi analisis penelitian. Dalam penelitian ini, hipotesis yang digunakan adalah sebagai berikut :

1 : Pengawasan internal mempunyai pengaruh yang positif dan signifikan terhadap kinerja karyawan.

2: Kepemimpinan mempunyai pengaruh yang positif dan signifikan terhadap kinerja karyawan karyawan.

3: Pengawasan Internal dan Kepemimpinan secara simultan mempunyai pengaruh positif dan signifikan terhadap kinerja karyawan.

\section{METODE PENELITIAN}

\section{A. Pendekatan Penelitian}

Pendekatan yang digunakan dalam penelitian ini adalah pendekatan kuantitatif, yaitu penelitian yang menekankan analisisnya pada data numerical atau angka yang diperoleh dengan metode statistik serta dilakukan pada penelitian inferensial atau dalam rangka pengujian hipotesis sehingga diperoleh signifikansi hubungan antara variabel yang diteliti. 


\section{B. Operasionalisasi Variabel}

Operasionalisasi variable dari penelitian yang diangkat penulis terdiri dari Variabel pengawasan internal (X1) dan kepemimpinan (X2) sebagai variable yang memengaruhi atau disebut juga sebagai variabel penyebab, atau sering disebut sebagai variabel bebas atau independent variable (X), serta Variable Kinerja Karyawan (Y) sebagai variabel akibat disebut variabel variabel tergantung atau dependent variable.

Tabel 1. Kisi-Kisi Variabel

\begin{tabular}{|c|c|c|c|c|c|}
\hline No & Varibel & Dimensi & Indikator & No Item & $\begin{array}{l}\text { Jumlah } \\
\text { item }\end{array}$ \\
\hline & \multirow{3}{*}{$\begin{array}{l}\text { pengawasan } \\
\text { internal } \\
\text { (Mangkunegar } \\
\text { a, 2009: 14) }\end{array}$} & $\begin{array}{l}\text { Dimensi atribut } \\
\text { individu, }\end{array}$ & $\begin{array}{l}\text { Kemampuan, Keahlian, } \\
\text { Latar belakang }\end{array}$ & $1,2,3$ & 3 \\
\hline & & $\begin{array}{ll}\begin{array}{l}\text { Dimensi } \\
\text { kerja } \\
\text { effort), }\end{array} & \text { upaya } \\
\text { (work }\end{array}$ & $\begin{array}{l}\text { Persepsi, Attitude, Personality } \\
\text { Pembelajaran } \\
\text { Motivasi }\end{array}$ & $4,5,6,7,8$ & 5 \\
\hline & & $\begin{array}{l}\text { Dimensi } \\
\text { dukungan } \\
\text { organisasi }\end{array}$ & $\begin{array}{l}\begin{array}{l}\text { Sumber daya, Kepemimpinan, } \\
\text { enghargaan, } \\
\text { organisasi. }\end{array} \\
\end{array}$ & $9,10,11,12$ & 4 \\
\hline & \multirow{3}{*}{$\begin{array}{l}\text { epemimpinan } \\
\text { Amirullah dan } \\
\text { Budiyono } \\
(2004 \text { : 244- } \\
262)\end{array}$} & $\begin{array}{l}\text { Efektifitas } \\
\text { Kepemimpinan }\end{array}$ & $\begin{array}{l}\text { Pengambilan Keputusan } \\
\text { Fungsi Kepemimpinan Bersikap } \\
\text { Ramah Mudah Ditemui }\end{array}$ & $13,14,15,16$ & 4 \\
\hline & & $\begin{array}{l}\text { Perilaku } \\
\text { kepemimpinan }\end{array}$ & $\begin{array}{l}\text { Supportif Direktif } \\
\text { Partisipatif } \\
\text { Orientasi Prestasi }\end{array}$ & $17,18,19,20$ & 4 \\
\hline & & $\begin{array}{l}\text { Motivasi } \\
\text { Kepemimpinan }\end{array}$ & $\begin{array}{l}\text { Kemampuan memotivasi } \\
\text { bawahan } \\
\text { Reward and Punishment }\end{array}$ & 21,22 & 2 \\
\hline & \multirow{5}{*}{$\begin{array}{l}\text { Kinerja } \\
\text { Sumber: Steph } \\
\text { en P. Robins } \\
(1994: 56) ; \\
\text { Gery Dessler } \\
\text { (1995 ; } \\
\text { 57) dalam } \\
\text { Pabundu } \\
(2004: \text { 121- } \\
128)\end{array}$} & 1. Kualitas kerja & $\begin{array}{l}\text { Menyelesaikan } \\
\text { pekerjaan sesuai mekanisme } \\
\text { Bekerja keras }\end{array}$ & 23,24 & 2 \\
\hline & & 2. Kuantitas kerja & $\begin{array}{l}\text { Bekerja secara tim } \\
\text { Saling mengisi dan mendukung }\end{array}$ & 25,26 & 2 \\
\hline & & $\begin{array}{lrl}3 . & \text { Lama jam } \\
\text { kerja } & & \\
\end{array}$ & $\begin{array}{l}\text { Masuk dan pulang sesuai waktu } \\
\text { Absensi selalu baik }\end{array}$ & 27,28 & 2 \\
\hline & & 4. Kerja sama & $\begin{array}{l}\text { Memberikan tanggungjawab } \\
\text { penuh Memberi penjelasan } \\
\text { dengan baik }\end{array}$ & 29,30 & 2 \\
\hline & & 5. Supervisi & $\begin{array}{l}\text { Tugas sesuai kemampuan } \\
\text { Sesuai dengan waktu dan } \\
\text { jumlah pekerjaan }\end{array}$ & 31,32 & 2 \\
\hline
\end{tabular}

C. Jenis dan Teknik Pengumpulan Data

Pendekatan yang digunakan dalam penelitian ini adalah pendekatan survei yaitu penelitian yang mengambil sampel dari satu populasi dan menggunakan kuesioner sebagai alat pengumpulan data yang pokok (Singarimbun, $1995: 3$ ).

\section{Populasi dan Sampel}

\section{Populasi}

Populasi adalah keseluruhan subyek penelitian (Arikunto, 2006: 130). Dengan menetapkan populasi, inidimaksudkan agar suatu penelitian dapat mengukur sesuatu sesuai dengan kasusnya dan tidak berlebihan denganpopulasi yang diacu. Jumlah populasi karyawan adalah 230 orang 


\section{Sampel}

Yang dimaksud dengan sampel adalah sebagian atau wakil populasi yang diteliti (Arikunto, 2006: 131). Sesuai dengan pemahaman diatas, maka sampel dalam penelitian ini adalah sebagian atau wakil yang sudah ditentukan.

\section{Teknik pengambilan sampel}

Teknik pengambilan sampel dalam penelitian ini adalah Sitratified Random Sampling). Yaitu pengambilan sampel berdasarkan strata atau tingkatan (Sugiyono, $2010 ; 34$ ).

$\mathrm{n}=\mathrm{N} /\left(1+\mathrm{Ne}^{2}\right)$,

Jumlah sample diambil dengan menggunakan rumus Slovin yaitu :

Dimana :

$\mathrm{n}=$ jumlah sampel

$\mathrm{N}=$ Jumlah populasi

$\mathrm{e}=$ tingkat kesalahan $(10 \%)$

Berdasarkan rumus di atas, maka jumlah sample dapat dihitung sebagai berikut :

$\mathrm{n}=230 /\left(1+230 .(0.1)^{2}\right)$

$\mathrm{n}=230 /(1+230(0.01))$

$\mathrm{n}=230 /(1+2.3)$

$\mathrm{n}=230 / 3.3$

$\mathrm{n}=70$

\section{Sumber data}

Terdiri dari Data primer dan Data Data sekunder

\section{Teknik pengumpulan data}

Untuk memperoleh data secara terperinci dan baik, maka peneliti menggunakan 2 metode, yaitu Kuesioner dan dokumentasi.

\section{Skala pengukuran}

Dalam penelitian ini pemberian skor menggunakan skala Likert yaitu dengan menghadapkan seorang responden dengan sebuah pernyataan dan kemudian diminta untuk memberikan jawaban: "sangat setuju", "setuju", "ragu-ragu", "tidak setuju", "sangat tidak setuju" (Singarimbun, 1995: 111). Dengan Bobot penilaian sebagai berikut :

\section{Tabel 2. Bobot nilai setiap pertanyaan}

\begin{tabular}{|l|c|}
\hline Alternatif Jawaban & Bobot Nilai \\
\hline Sangat setuju, Sangat Penting, sangat memuaskan, selalu & 5 \\
\hline Setuju, penting, memuaskan, sering & 4 \\
\hline Netral, biasa, cukup memuaskan, kadang-kadang & 3 \\
\hline Tidak setuju, tidak penting, tidak memuaskan, jarang & 2 \\
\hline Sangat tidak setuju, Sangat tidak penting, sangat tidak memuaskan, tidak pernah & 1 \\
\hline
\end{tabular}

\section{E. Uji Keabsahan Data}

1. Validitas

Validitas alat ukur bertujuan untuk mengetahui sejauhmana skala yang digunakan mampu menghasilkan data yang akurat sesuai tujuan ukurnya. Uji dilakukan dengan membandingkan nilai $r$ hitung dan $r$ kritis ( $r$ kritis $=0,30)$. Kriteria jika $r$ hitung lebih besar $(>)$ dari nilai $r$ kritis, item instrument dinyatakan valid (sugiyono, 2007 ; 134). Selain itu menurut Cooper (2000), instrument dinyatakan valid jika $r$ hitung lebih besar (>) daripada $r$ table. 
2. Reliabilitas

Uji reliabilitas yang digunakan untuk mengukur suatu kuesioner yang merupakan indikator dari variabel. Dalam penelitian ini kuesioner dikatakan reliabel jika jawaban seseorang terhadap kuesioner stabil dari waktu ke waktu. Sebuah faktor dinyatakan reliabel/andal jika koefisien Alpha lebih besar dari 0,6 .

3 Uji Persyaratan Analisis (Asumsi Klasik)

Dalam pengolahan data, perlu dilakukan uji persyaratan analisis mencakup: Uji Normalitas, Uji Multikolinieritas, Uji Autokorelasi, dan Uji Heterokedastisitas

\section{a. Analisis Regresi Linear Berganda}

Tujuan digunakannya analisis regresi linier berganda ini adalah untuk mengetahui apakah variabel bebas secara bersama-sama mempengaruhi variabel terikat.

$\mathrm{Y}=\mathrm{b} 1 \mathrm{X} 1+\mathrm{b} 2 \mathrm{X} 2+\mathrm{e}$

Dimana:

$\mathrm{Y}=$ pengawasan internal

b1 $=$ Koefisien regresi pengawasan internal

b2 $=$ Koefisien regresi Kepemimpinan

$\mathrm{X} 1=$ pengawasan internal

$\mathrm{X} 2=$ Kepemimpinan

$\mathrm{e}=$ Varians pengganggu

b. Pengujian Hipotesis

1) Uji statistik t

Tujuan dari uji statistik t ini adalah untuk mengetahui seberapa jauh pengaruh satu variabel independen secara individual dalam menerangkan variabel dependen.

\section{1) Uji Statistik F}

Tujuan dari uji statistik $\mathrm{F}$ ini pada dasarnya adalah menunjukkan apakah semua variabel bebas yang dimasukkan dalam model mempunyai pengaruh secara bersamasama terhadap variabel terikat.

c. Koefisien Determinasi

Koefisien Determinasi $\left(\mathrm{R}^{2}\right)$ digunakan untuk mengukur seberapa jauh kemampuan model dalam menerangkan variasi variabel dependen. Nilai koefisien determinasi ada diantara nol dan satu. Nilai $\mathrm{R}^{2}$ yang kecil berarti kemampuan variabel-variabel independen dalam menjelaskan variasi variabel dependen amat terbatas. Nilai $R^{2}$ yang mendekati satu berarti variabel-variabel independen memberikan hampir semua informasi yang dibutuhkan untuk memprediksi variasi-variasi dependen (Kuncoro, 2001).

\section{F. Lokasi dan Jadwal Penelitian}

Tempat penelitian dilakukan di Politeknik LP3I Jakarta sekitar bulan Juni 2014 s/d Agustus 2014.

\section{HASIL PENELITIAN}

\section{Deskripsi Responden}

Responden dalam penelitian ini adalah semua karyawan Politeknik LP3I Jakarta. Jumlah warga belajar yang dipilih sebagai responden sebanyak 70 orang dengan identitas sebagai berikut.

a. Usia Responden

Usia responden relative homogen dengan kisaran umur antara $18 \mathrm{~s} / \mathrm{d} 60$ tahun.

b. Bidang Pekerjaan

Penggolongan responden menurut tingkat pendidikannya dikelompokkan dalam tabel 4.3 berikut ini: 
Tabel 3. Distribusi Responden menurut Bidang Pekerjaaan

\begin{tabular}{|l|c|c|c|}
\hline $\begin{array}{l}\text { Bidang } \\
\text { Pekerjaaan }\end{array}$ & $\begin{array}{l}\text { Jumlah } \\
\text { Karyawa } \\
\text { n }\end{array}$ & FrekuensI & Prosentase(\%) \\
\hline Pendidikan & 58 & 18 & 13.48 \\
\hline Marketing & 61 & 19 & 13.04 \\
\hline Keuangan & 38 & 12 & 10.00 \\
\hline SDM & 17 & 5 & 3.04 \\
\hline Umum & 21 & 6 & 4,35 \\
\hline Administrasi & 35 & 10 & 10.00 \\
\hline Jumlah & $\mathbf{2 3 0}$ & $\mathbf{7 0}$ & $\mathbf{1 0 0}$ \\
\hline
\end{tabular}

Sumber : Data Primer yang diolah,2014

\section{Uji Validitas dan Uji Reliabilitas}

\section{1). Uji Validitas}

Dari hasil pengolahan data menunjukkan nilai $r$ hitung lebih besar dari $r$ tabel $(0,196)$ dengan demikian dapat disimpulkan bahwa semua item dalam indikator variabel pengawasan internal, Kepemimpinan dan Kinerja Karyawan adalah valid.

\section{Uji Reliabilitas}

Berdasarkan hasil olah data dapat diketahui bahwa masing-masing variabel antara variabel pengawasan internal, kepemimpinan, dan kinerja karyawan, ternyata diperoleh nilai Cronbach Alpha $\geq 0,60$. Dengan demikian, maka hasil uji reabilitas terhadap keseluruhan variabel adalah reliabel.

\section{Analisis Kuantitatif}

\section{a. Uji Asumsi Klasik}

1) Uji Multikolinearitas

Tabel 14. Tabel Hasil Uji Multikolinearitas

\begin{tabular}{|ll|r|r|}
\hline \multirow{2}{*}{ Odel } & \multicolumn{2}{|c|}{ Collinearity Statistics } \\
\cline { 3 - 4 } & & Tolerance & VIF \\
\hline 1 & (Constant) & & \\
& pengawasan_Internal & .471 & 2.124 \\
& Kepemimpinan & .471 & 2.124 \\
\hline
\end{tabular}

Sumber : data Primer yang Diolah, 2014

Berdasarkan hasil tersebut maka dalam model regresi tidak terjadi multikolinearitas atau korelasi yang sempurna antara variabel-variabel bebas, yaitu pengawasan internal, harga dan lokasi, karena nilai VIF lebih kecil dari 10 dan nilai tolerance lebih besar dari 0,1 . 
Gambar 4. Pengujian Heteroskedastisitas

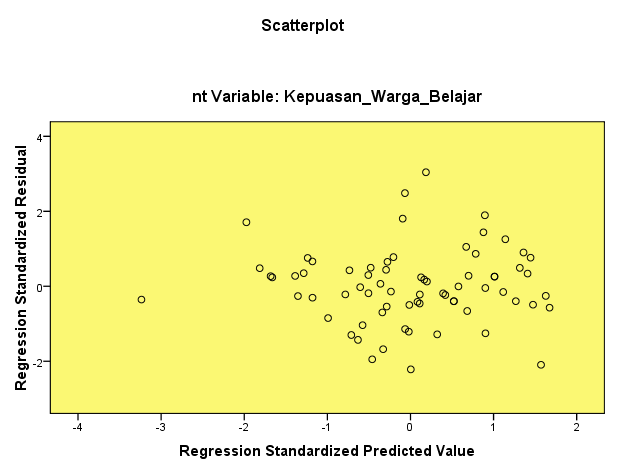

Sisaan Homogen (Asumsi terpenuhi)

Gambar 4. Gambar Hasil Uji Heterokedastisitas

Sumber : Data primer yang diolah, 2014

Dari grafik tersebut, dapat terlihat titik-titik yang menyebar secara acak, tidak membentuk suatu pola tertentu yang jelas, serta tersebar baik di atas maupun di bawah angka 0 (nol) pada sumbu Y, maka tidak terjadi heteroskedastisitas.

\section{1) Uji Normalitas}

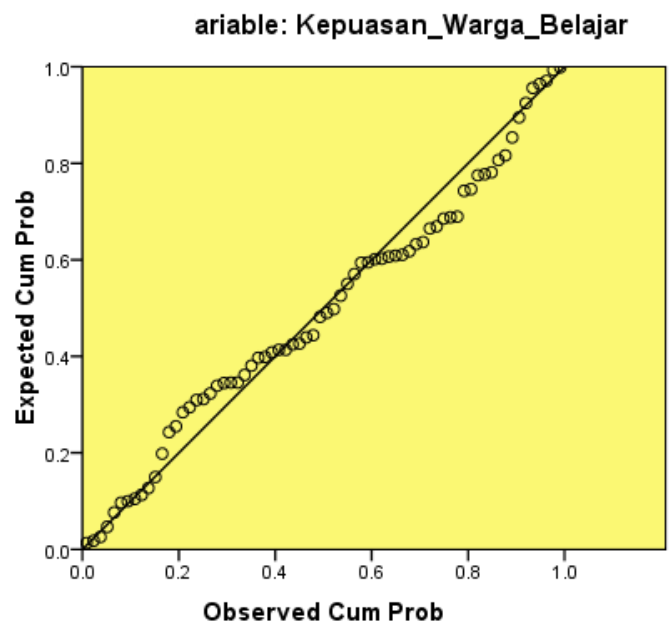

Normalitas (Sisaan menyebar normal: Asumsi Terpenuhi)

Gambar 5. Hasil Pengujian Normalitas

Sumber : Data primer yang diolah, 2014

Berdasarkan hasil analisis data dengan menggunakan SPSS, maka dapat diketahui bahwa data menyebar disekitar garis diagonal dan mengikuti arah garis diagonal, maka model regresi memenuhi asumsi normalitas.

\section{4) Analisis Regresi Linier Berganda}

Berdasarkan perhitungan regresi berganda antara pengawasan internal (X1), kepemimpinan (X2) terhadap kinerja karyawan (Y) dengan dibantu program SPSS dalam perhitungannya dapat diperoleh hasil sebagai berikut 
Tabel 15. Tabel Ringkasan Hasil Estimasi Regresi

\begin{tabular}{|c|c|c|c|c|c|}
\hline \multirow[b]{2}{*}{ Model } & \multicolumn{2}{|c|}{$\begin{array}{c}\text { Unstandardized } \\
\text { Coefficients } \\
\end{array}$} & \multirow{2}{*}{\begin{tabular}{|c|}
$\begin{array}{c}\text { Standardized } \\
\text { Coefficients }\end{array}$ \\
Beta \\
\end{tabular}} & \multirow[b]{2}{*}{$\mathrm{t}$} & \multirow[b]{2}{*}{ Sig. } \\
\hline & B & Std. Error & & & \\
\hline $1 \quad$ (Constant) & -12.882 & 6.748 & & -1.909 & .061 \\
\hline Kemampuan Ajar & .852 & .136 & .580 & 6.264 & .000 \\
\hline MediaPembelajaran & .352 & .098 & .333 & 3.600 & .001 \\
\hline
\end{tabular}

a. Dependent Variable: Kinerja Karyawan

Sumber : Data primer yang diolah, 2014

Berdasarkan tabel di atas, maka persamaan regresi yang terbentuk pada uji regresi ini adalah :

$\mathrm{Y}=-12.882+0.852 \mathrm{X} 1+0.352 \mathrm{X} 2$.

Berdasarkan persamaan dapat diketahui bahwa

a) Nilai koefisien regresi variabel pengawasan internal sebesar 0,852 bernilai positif mempunyai arti bahwa jika pengawasan internal semakin baik, maka kinerja karyawan akan meningkat.

b) Nilai koefisien regresi variabel Kepemimpinan 0.352 bernilai positif mempunyai arti bahwa jika kepemimpinan semakin baik, maka kinerja karyawan akan meningkat.

\section{5). Pengujian Hipotesis}

1. Uji t

a) Pengawasan internal Mempunyai Pengaruh Yang Positif Terhadap Kinerja karyawan

Berdasarkan hasil perhitungan diperoleh nilai t hitung untuk variabel pengawasan internal adalah sebesar 6.624 dan dengan menggunakan level significance (taraf signifikasi) sebesar 5\% diperoleh t tabel sebesar 2.92 yang berarti bahwa nilai t hitung lebih besar dari t tabel yaitu $6.624>2.92$ Nilai signifikasi t kurang dari $5 \%(0,000)$, menandakan bahwa pengawasan internal (X1) mempunyai pengaruh yang positif dan signifikan terhadap kinerja karyawan (Y). Dengan demikian dapat disimpulkan bahwa Ho ditolak dan H1 diterima, sehingga hipotesis yang menyatakan pengawasan internal mempunyai pengaruh yang positif terhadap kinerja karyawan dapat diterima.

\section{b) Kepemimpinan Mempunyai Pengaruh Yang Positif Terhadap Kinerja karyawan}

Berdasarkan hasil perhitungan diperoleh nilai t hitung untuk variabel harga adalah sebesar 3.600 dan dengan menggunakan level significance (taraf signifikasi) sebesar 5\% diperoleh $\mathrm{t}$ tabel sebesar 2.92 yang berarti bahwa nilai t hitung lebih besar dari t tabel yaitu $3.600>2.92$. Nilai signifikasi t kurang dari $5 \%$ (0,000), menandakan bahwa kepemimpinan (X2) mempunyai pengaruh yang positif dan signifikan terhadap kinerja karyawann (Y). Dengan demikian dapat disimpulkan bahwa Ho ditolak dan H1 diterima, sehingga hipotesis yang menyatakan kepemimpinan mempunyai pengaruh yang positif terhadap kinerja karyawan dapat diterima.

\section{6) Uji F}

Dalam melakukan uji F, parameter yang digunakan adalah dengan membandingkan F-hitung > Ftabel. Pengujian terhadap pengaruh variabel bebas terhadap variabel terikat secara simultan dilakukan dengan uji $\mathrm{F}$ dengan hasil yang dapat dilihat pada tabel 4.7 berikut ini. 
Tabel 16. Tabel Nilai $\boldsymbol{U j i} \boldsymbol{F}$

ANOVA

ANOVA ${ }^{b}$

\begin{tabular}{|ll|r|r|r|c|c|}
\hline Model & & Sum of Squares & Df & Mean Square & F & Sig. \\
\hline 1 & Regression & 13444.618 & 2 & 6722.309 & 90.265 & .000 \\
& Residual & 4989.719 & 67 & 74.473 & & \\
Total & 18434.338 & 69 & & & \\
\hline
\end{tabular}

a. Predictors: (Constant), pengawasan internal, Kepemimpinan

b. Dependent Variable: Kinerja karyawan

Sumber : Data primer yang diolah 2014

Dari tabel 4.7. menunjukkan hasil perhitungan uji F diperoleh nilai F-hitung sebesar 90.265 dengan tingkat signifikansi sebesar 0,000 $(<0,05)$. Sementara nilai F-tabel sebesar 3.1338 (dari perhitungan dk1 $=2$, alpha $=0,05$ dan $\mathrm{dk}=70-2-1=67$ diperoleh $\mathrm{F}$ table 3.1338). Ini berarti bahwa F-hitung (90.265) > Ftabel (3.1338) dengan demikian Ho ditolak dan H1 diterima, artinya bahwa pengawasan internal dan kepemimpinan berpengaruh secara simultan atau bersama-sama terhadap kinerja karyawan.

\section{7) Korelasi Product Moment (Korelasi dan Determinasi)}

\section{1) Korelasi Hubungan antara pengawasan internal dengan Kinerja karyawan}

Tabel 17 Model Summary Koefisien Determinasi

\begin{tabular}{|l|l|l|l|l|}
\hline Model & & $\begin{array}{l}\text { Model Summary } \\
\text { Square }\end{array}$ & $\begin{array}{l}\text { Adjusted } \\
\text { Square }\end{array}$ & $\begin{array}{l}\text { Std. Error of the } \\
\text { Estimate }\end{array}$ \\
\hline 1 & $823^{\mathrm{a}}$ & .677 & .665 & 8.62980 \\
\hline
\end{tabular}

a. Predictors: (Constant), Pengawasan Internal

b. Dependent Variable: Kinerja Karyawan

Sumber : Data Primer yang Diolah, 2014

Dari table di atas dapat diketahui bahwa besarnya nilai koefisien korelasi antara pengawasan internal dan Kinerja karyawan ditunjukkan oleh nilai $\mathrm{r}$ sebesar 0.823 yang berarti hubungan diantara keduanya kuat. Sedangkan nilai Koefesien Determinasi $\left(\mathrm{R}^{2}\right)$ adalah sebesar 0,677 yang artinya bahwa pengawasan internal dapat menerangkan variabel kinerja karyawan sebesar 67,7 \%, sedangkan sisanya sebesar $32,3 \%$ diterangkan oleh variabel lain yang tidak diajukan dalam penelitian ini.

2) Korelasi Hubungan antara Kepemimpinan dengan Kinerja karyawan

Tabel 18 Model Summary Koefisien Determinasi Model Summary ${ }^{\mathrm{b}}$

\begin{tabular}{|l|l|l|l|l|l|}
\hline Model & $\mathrm{R}$ & $\begin{array}{l}\mathrm{R} \\
\text { Square }\end{array}$ & $\begin{array}{l}\text { Adjusted } \\
\text { Square }\end{array}$ & $\begin{array}{l}\text { Rtd. Error of the } \\
\text { Estimate }\end{array}$ \\
\hline 1 & $.756^{\mathrm{a}}$ & .571 & .568 & .43362 \\
\hline
\end{tabular}

a. Predictors: (Constant),

b. Dependent Variable: Kinerja Karyawan

Sumber : Data Primer yang Diolah, 2014 
Berdasarkan data table di atas dapat diketahui bahwa besarnya nilai koefisien korelasi antara Kepemimpinan dan Kinerja karyawan ditunjukkan oleh nilai $\mathrm{r}$ sebesar 0.756 yang berarti hubungan diantara keduanya sangat kuat. Sedangkan nilai Koefesien Determinasi $\left(\mathrm{R}^{2}\right)$ adalah sebesar 0.571 yang artinya bahwa pengawasan internal dapat menerangkan variabel kinerja karyawan sebesar 57,1 $\%$, sedangkan sisanya sebesar $42,9 \%$ diterangkan oleh variabel lain yang tidak diajukan dalam penelitian ini.

\section{3) Koefisien Determinasi antara pengawasan internal dan Kepemimpinan dengan Kinerja karyawan}

Untuk mengetahui besarnya pengaruh pengawasan internal dan kepemimpinan terhadap kinerja karyawan dapat dilihat dari besarnya nilai adjusted $\mathrm{R}^{2}$

Tabel 19. Model Summary Koefisien Determinasi

Model Summary ${ }^{\mathrm{b}}$

\begin{tabular}{|l|l|l|l|l|}
\hline Model & $\mathrm{R}$ & $\begin{array}{l}\mathrm{R} \\
\text { Square }\end{array}$ & $\begin{array}{l}\text { Adjusted } \\
\text { Square }\end{array}$ & $\begin{array}{l}\text { Std. Error of the } \\
\text { Estimate }\end{array}$ \\
\hline 1 & $.854^{\mathrm{a}}$ & .729 & .721 & .43788 \\
\hline
\end{tabular}

a. Predictors: (Constant), pengawasan internal, kepemimpinan

b. Dependent Variable: Kinera_Karyawan

Sumber : Data Primer yang Diolah, 2014

Berdasarkan tabel di atas, dapat diketahui bahwa besarnya nilai koefisien determinasi ditunjukkan oleh nilai R Square yaitu sebesar 0.729 yang artinya bahwa variasi dari semua variabel bebas yaitu pengawasan internal dan kepemimpinan dapat menerangkan variabel kinerja karyawan sebesar $72.9 \%$, sedangkan sisanya sebesar $27.1 \%$ diterangkan oleh variabel lain yang tidak diajukan dalam penelitian ini.

\section{PEMBAHASAN}

Berdasarkan hasil penelitian yang penulis lakukan di Politeknik LP3I Jakarta, dengan melibatkan sebanyak 70 orang responden, yang memberikan informasi mengenai pengaruh dari variabel pengawasan internal dan kepemimpinan terhadap kinerja karyawan. Dari hasil penelitiandiperoleh nilai $\mathrm{R}$ square sebesar 0.729 yang artinya bahwa variasi dari semua variabel bebas yaitu pengawasan internal dan kepemimpinan dapat menerangkan variabel kinerja karyawan sebesar 72.9\%, sedangkan sisanya sebesar $27.1 \%$ diterangkan oleh variabel lain yang tidak diajukan dalam penelitian ini.

Dari tabel uji validitas dapat diketahui bahwa variabel pengawasan internal dan kepemimpinan serta kinerja karyawan mempunyai $r$ hitung yang lebih besar daripada $r$ kritis 0,3 , sehingga dapat dikatakan bahwa semua indikator pertanyaan yang digunakan dalam penelitian ini adalah valid. Sedangkan dari tabel uji reliabilitas dapat diketahui bahwa masing-masing variabel antara pengawasan internal, kepemimpinan dan kinerja karyawan diperoleh nilai Cronbach Alpha $\geq 0,60$. Dengan demikian, maka hasil uji reabilitas terhadap keseluruhan variabel adalah reliabel.

Dari gambar grafik distribusi normalitas menunjukkan bahwa titik-titik menyebar di sekitar garis diagonal dan mengikuti arah garis diagonal. Dengan demikian menunjukan pola distribusi yang normal, maka model regresi memenuhi asumsi normalitas. Dari tabel multikolinearitas dapat diketahui bahwa nilai Variance Inflation faktor ( VIF ) dari masing masing variabel bebas lebih kecil dari angka 10, dan nilai tolerance lebih besar dari 0,1 . Sehingga dapat disimpulkan bahwa pada uji regresi tersebut tidak terdapat problem multikolinieritas, maka model yang ada layak untuk dipakai. Dari gambar heteroskedastisitas terdeteksi titik-titik yang ada adalah menyebar, dan tidak membentuk pola tertentu, sehingga tidak terjadi heteroskedastisitas.

Dari uji t diketahui bahwa nilai $\mathrm{t}$ hitung $>\mathrm{t}$ tabel dan tingkat signifikan $<0,05$ hanya untuk variabel kepemimpinan. Sehingga dapat disimpulkan bahwa variabel kepemimpinan secara parsial berpengaruh terhadap kinerja karyawan. Dari uji $\mathrm{F}$ juga di ketahui bahwa $\mathrm{F}$ hitung $>\mathrm{F}$ tabel dan tingkat signifikasi $<0,05$ sehingga dapat disimpulkan bahwa variabel pengawasan internal dan kepemimpinan secara bersama-sama berpengaruh terhadap kinerja karyawan. 
Dengan melihat hasil penelitian di atas, terlihat bahwa korelasi (kaitan) antara pengawasan internal dan kepemimpinan dengan kinerja karyawan terlihat memiliki pengaruh yang kuat. Hal tersebut ditunjukkan dengan nilai koefisien korelasi sebesar 0.854. Adapun kontribusi pengawasan internal dan kepemimpinan terhadap kinerja karyawan memiliki prosentase yang sangat besar. Hal tersebut ditunjukkan oleh koefisien determinasi sebesar $72.9 \%$.

Kita menyadari bahwa kinerja karyawan merupakan faktor yang menentukan eksisitensi perusahaan, karena kita mengetahui bahwa kehadiran persaingan perusahaan berjalan sangat ketat, sehinga disadari atau tidak, langsung maupun tidak langsung, tingkat kinerja karyawan ini akan menjadi faktor yang sangat menentukan apakah perusaah ungul atau tidak dalam suatu persaingan.

Dengan demikian faktor kinerja karyawan tersebut haruslah disikapi dengan bijak oleh setiap perusahaan, jika perusahaan tersebut ingin tetap eksis, maju dan berkembang.

Kita mengetahui bahwa setiap perusahaan senantiasa berusaha semaksimal mungkin untuk meningkatkan keuntungan setinggi-tingginya melaui tingginya kinerja karyawan. Berbagai upaya dilakukan untuk meningkatkan keuntungan perusahaan, salah satu diantaranya adalah dengan meningkatkan kinerja karyawan. Untuk menciptakan kinerja karyawan tersebut jelas harus pengawasan internal dan kepemimpinan dengan baik.

Sehingga dengan demikian kunci pengembangan perusahaan terletak pada kinerja karyawannya, yang berarti bahwa jika perusahaan ingin senantiasa eksis, maju dan berkembang, maka ia harus meningkatkan kinerja karyawannya.

\section{KESIMPULAN}

Berdasarkan hasil analisis data yang telah dilakukan terhadap seluruh data yang diperoleh, maka dapat diambil kesimpulan sebagai berikut :

1 Pengawasan internal berpengaruh terhadap kinerja karyawan

2 Kepemimpinan berpengaruh terhadap kinerja karyawan

3 Pengawasan internal dan kepemimpinan memiliki pengaruh terhadap kinerja karyawan

4 Hubungan pengawasan internal dan kepemimpinan terhadap kinerja karyawan adalah sangat kuat.

\section{SARAN}

Berdasarkan kesimpulan yang telah dikemukakan, maka diberikan beberapa saran yang diharapkan dapat meningkatkan kinerja karyawan Politeknik LP3I Jakarta. Adapun saran-saran yang diberikan bagi perusahaan adalah sebagai berikut:

1. Berdasarkan data hasil questionare diperoleh indek pengawasan internal berdasarkan skala likert sebesar 3.86, yang berarti pengawasan internal dinilai sudah cukup baik, sehingga dengan demikian perlu dipertahankan kualitasnya, bahkan kalau perlu lebih ditingkatkan lagi dengan cara meningkatkan attitude kerja karyawan, sumber daya untuk menggerakan roda aktifitas kegiatan perusahaan, kepemimpinan serta pembenahan struktur organisasi

2. Berdasarkan data hasil questionare diperoleh indek kepemimpinan berdasarkan skala likert sebesar 3.92, yang berarti kepemimpinan dinilai warga belajar sudah cukup baik, namun agar hasilnya lebih baik lagi, maka perlu ditingkatkan lagi dengan cara memperbaiki pengambilan keputusan, peningkatan pasrtisifasi kepemimpinan, orientasi pimpinan terhadap prestasi karyawan, motivasi pimpinan serta peningkatan reward and punishment pimpinan atas kinerja karyawan.

3. Berdasarkan data hasil questionare diperoleh indek Kinerja Karyawan berdasarkan skala likert sebesar 3.82, yang berarti kinerja karyawan dinilai sudah cukup baik, namun agar hasilnya lebih memuaskan mereka lagi, maka perlu meningkatkan upaya-upaya kepuasan mereka dengan cara meningkatkan kemampuan karyawan sesuai mekanisme, kemampuan kerja tim karyawan, kemampuan karyawan untuk saling mengisi dan mendukung, kedisiplinan jam masuk dan pulang karyawan sesuai waktu, absensi, serta tanggung jawan kerjasama karyawan yang penuh.

\section{DAFTAR PUSTAKA}

Arikunto, Suharsimi. (2006). Prosedur Penelitian Suatu Pendekatan Praktik. Jakarta: PT Asdi Mahasatya. Bambang Hartadi. (1999). Sistem pengawasan internal. Yogyakarta: BPFE. 
Darwito. (2008). Analisis Pengaruh Gaya Kepemimpinan Terhadap Kepuasan Kerja dan Komitmen Organisasi Untuk Meningkatkan Kinerja Karywan (Studi pada RSUD Semarang). Tesis. Magister Manajemen Program Pasca Sarjana Universitas Diponegoro.

Eka Nuraini Rachmawati. (2004). Paradigma Baru Manajemen Sumber Daya Manusia Sebagai Basis Meraih Keunggulan Kompetitif. Yogyakarta:

Hadari Nawawi. (2006). Evaluasi dan Manajemen Kinerja di Lingkungan Perusahaan dan Industri. Yogyakarta: UGM Press.

Hasibuan, Malayu S.P. (2003). Manajemen Sumber Daya Manusia. Jakarta: Bumi Aksara Imam Ghozali. (2009). Aplikasi Analisis Multivariat Dengan Program SPSS. Semarang: UNDIP. Sugiyono. (2009). Metode Penelitian Kuantitatif Kualitatif dan R\&D. Bandung: ALFABETA.

Wirawan. (2009). Evaluasi Kinerja Sumber Daya Manusia. Jakarta: Salemba Empat. 